\title{
Ultrastructure of fish cells involved in cellular defences against Saprolegnia infections: evidence of non-leucocytic nature
}

\author{
M. V. López-Dóriga, J. L. Martínez* \\ Dpto. Biología de Organismos y Sistemas, Universidad de Oviedo, c/ Catedrátigo Rodrigo Uría s/n, E-33071 Oviedo, Spain
}

\begin{abstract}
Fish cells attached to hyphae were observed in brown trout Salmo trutta L. infected with Saprolegnia parasitica. Earlier studies with light microscopy indicated that these cells were lymphocytes and neutrophils and that they were involved in the defence mechanisms against Saprolegnia infections. However, using electron microscopy, we found these attached cells did not show leucocytic characteristics, but instead shared some ultrastructural features with filament-containing cells. The presence of a dense mass of cytoplasmic filaments precludes the leucocytic nature of these cells. How these cells could be involved in cellular defences against fungl is discussed.
\end{abstract}

KEY WORDS: Saprolegnia infection - Attached fish cells - Cellular defences Non-leucocytic cells Salmonid - Ultrastructure

\section{INTRODUCTION}

Members of the family Saprolegniaceae (Oomycota) are the most frequent and important fungal parasites in aquatic animals (Alderman 1982, Willoughby 1994). Mycotic infections of freshwater fish, mainly salmonids, by Saprolegnia can occur at any stage of the fish's life cycle and are of economic importance to aquaculture.

As soon as a Saprolegnia infection has been successful, the organism makes up dense mycelium forming whitish patches that spread mainly along the surface of the body fish. Saprolegnia hyphae rarely penetrate into internal organs, usually being limited to the epidermis, dermis and superficial muscle (Pickering \& Willoughby 1982). However, in severe infections, the hyphae can also invade internal organs such as stomach (Willoughby 1994) and thymus (Álvarez et al. 1987, 1995)

In salmonid fish 3 defence components against Saprolegnia infections have been proposed (Wood et al. 1986, 1988; see review by Noga 1993):

\footnotetext{
-Addressee for correspondence.
}

E-mail: juanlm@sci.cpd.uniovi.es
(1) Physical removal of attached spores. Although Saprolegnia propagules can adhere to fish surface (Willoughby \& Pickering 1977), the continuous secretion of mucus by the epidermal goblet cells is an extremely effective mechanism removing small particles from the skin surface. Pickering \& Willoughby (1982) monitored the rate of loss of spores (Saprolegnia diclina Type 1) in rainbow trout Oncorhynchus mykiss, and found that over $95 \%$ of the viable spores were removed from mucus layer within 2 h after experimental challenge.

(2) Humoral factors. Defensive chemicals such as complement, antibodies, and lysozyme occur in fish skin mucus (Alexander 1985). Besides these, a morphogen inhibiting the mycelia growing from the spores but which did not kill the fungus was detected in the external mucus of a salmonid (Wood et al. 1988).

(3) Cellular defences. In infected skin a cellular response has been observed around invading hyphae. This response was first seen by Willoughby (1972), who observed cells attached to Saprolegnia parasitica germlings in mucus taken from naturally infected Arctic char Salvelinus alpinus. Later, Sohnle \& Chusid (1983) observed cells adhering to the surface of hyphae which had been experimentally implanted under the 
skin of rainbow trout $24 \mathrm{~h}$ before. These attached cells have only been observed by light microscopy and they have not been clearly identified. It is believed they are inflammatory cells, mainly lymphocytes and neutrophils (Sohnle \& Chusid 1983, Wood et al. 1986, 1988, Willoughby 1989). However, most studies indicate that in Saprolegnia infections there are no inflammatory responses either in tegumental (Pickering \& Richards 1980, Pickering \& Willoughby 1982, Xu \& Rogers 1991, Bly et al. 1992, López-Dóriga 1995) or inner infections (Bruno \& Stamps 1987, Álvarez et al. 1988, 1995). The lack of inflammatory response seems to be related to immunosuppressive factors since immunocompetent catfish experimentally infected with Saprolegnia were able to produce inflammatory processes (Bly et al. 1993)

During a wide-ranging ultrastructural study on epithelial Saprolegnia infections on brown trout (LópezDóriga 1995), fish cells attached to hyphae were frequently found, but apparently they showed no inflammatory characteristics. Because of these observations, we studied the ultrastructural features of these cells to try and elucidate their possible nature.

\section{MATERIALS AND METHODS}

Fish. Specimens of 2 to 3 yr old brown trout Salmo trutta L., 150 to $400 \mathrm{~g}$ in weight, naturally infected by Saprolegnia, were obtained from a hatchery at Infiesto (Asturias, Northern Spain), and kept in tanks at $10 \pm 2^{\circ} \mathrm{C}$. Skin samples were excised from fishes anaesthetised in MS222 (tricaine methane sulphonate) 1:15000.

Samples. Samples of fungi, including the underlying skin, were taken from the head and kept on sterile plates with filtered $(0.2 \mu \mathrm{m})$ and sterilised water taken from the fish farm. Fungus isolation was carried out according to Willoughby \& Pickering (1977) and Willoughby (1978) In order to identify the fungus involved in the infection, samples were observed daily with a stereomicroscope to study the formation and release of spores and their sexual structures

Pieces of unscaled and infected skin, including the growing margin of Saprolegnia colonies, were taken from the dorsal region of the head, and immediately fixed in $2 \%$ glutaraldehyde buffered at $\mathrm{pH} 7.2$ with 0.05 M PIPES (piperazine-N, $N^{\prime}$ bis 2-ethanesulfonic acid) (Hayat 1981)

Light and electron microscopy. For light microscopy (LM) and transmission electron microscopy (TEM) the samples were fixed for $6 \mathrm{~h}$ at room temperature. Tissue blocks were postfixed for $2 \mathrm{~h}$ in $2 \%$ osmium tetroxide in the same buffer (0.05 M PIPES), also used for washing These were left overnight at room temperature in $2 \%$ buffered uranyl acetate. Dehydration in a graded series of acetone was followed by embedding in Araldite (Durcupan ACM) using propylene oxide as an intermediate solvent.

Semi-thin sections $(0.5 \mu \mathrm{m})$ of plastic embedded tissue were stained with Toluidine blue and Basic fucsin (Spurlock et al. 1966). Ultra-thin sections were obtained with a LKB Ultratome IV, stained on copper grids in Fahmy's lead citrate (Lewis \& Knight 1977), and examined with a Philips EM-300 electron microscope.

For scanning electron microscopy (SEM) the tissues were fixed for $24 \mathrm{~h}$ at $4^{\circ} \mathrm{C}$. After washing in the buffer cited above, they were dehydrated in a graded series of ethanol. Samples were then critical-point dried in carbon dioxide (C.P. Polaron E-3000) using amyl acetate as an intermediate snlvent, mounted, sputtercoated with gold (Polaron E-5100), and examined with a Philips 500 scanning electron microscope.

\section{RESULTS}

Identification of the isolates was based on morphological and growth features. The isolates were cultured, and primary and secondary zoospores and cysts were observed, as well as oogonia and antheridia. The secondary cyst had groups of long hairs ( 7 to $10 \mu \mathrm{m}$ length) which were observed by phase contrast, light microscopy with dark field and electron microscopy. They germinated readily, forming septate germ tubes with the cytoplasmic material located in the distal area. According to Beakes et al. (1994) and Willoughby (1994), the fungus was identified as Saprolegnia parasitica.

In most of the samples taken from fish, cells adhering to the hyphal surfaces were observed (Fig. 1). These cells were numerous in the late phases of the infection, when the skin was invaded by hyphae and the epithelial structure had been lost. In semi-thin sections, hyphae were intermingled with filament-containing cells (FCCs), melanin granules, and dermal components (Fig, 2). Many hyphae appeared surrounded by intensely stained cells, with homogeneous cytoplasm (Fig. 3). When 2 or more cells surrounded 1 hypha, the cell membranes were pressed together.

When the periphery of the fungal lesion was observed by SEM, the growing edge of the mycelium could be clearly distinguished (Fig. 4). In this area, cells attached to hyphae could be frequently seen (Fig. 5). Because these cells were so closely attached to the fungal hyphae their morphology was variable. However, some of the attached cells clearly showed remnants of the superficial microridges which characterise the normal epidermal cells (Figs. 6 \& 7).

Ultrastructurally, these cells had both dense cytoplasm and nucleoplasm (Fig 8). In some less dense cells it was possible to distinguish organelles such as 


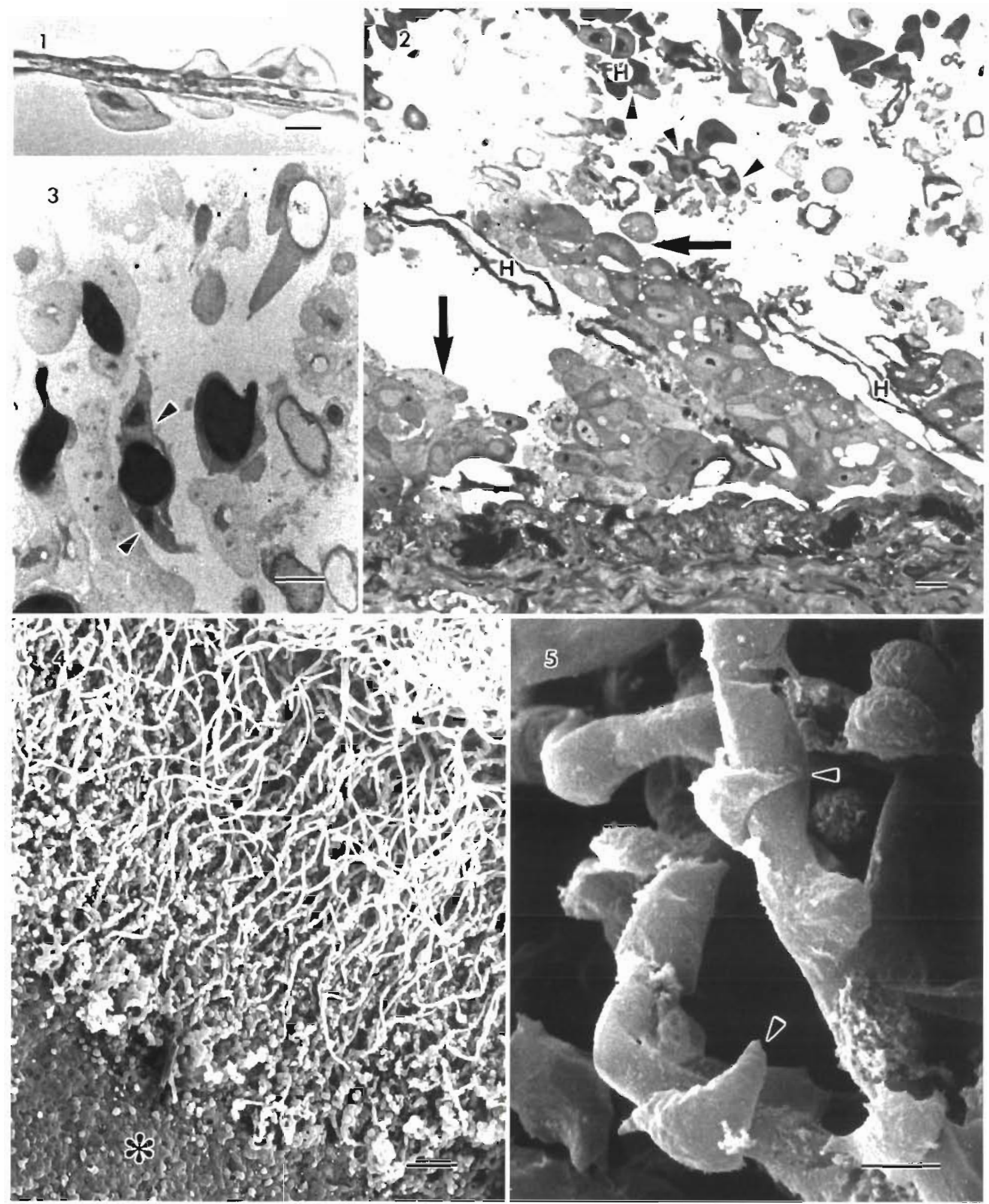

Figs. 1 to 5. Salmo trutta infected with Saprolegnia parasitica. Fig. 1 Saprolegnia hyphae with adhered fish cells from brown trout. Scale bar $=10 \mu \mathrm{m}$. Fig. 2. Severe Saprolegnia-infected integument from brown trout. Epithelial remains (arrows) with numerous hyphae $(\mathrm{H})$, some of them with attached cells (arrowheads). Toluidine blue \& Basic fucsin. Scale bar $=10 \mu m$. Fig. 3. Attached fish cells (arrowheads) appear deeply stained with homogeneous cytoplasm. Toluidine blue \& Basic fucsin. Scale bar $=10 \mu \mathrm{m}$. Fig. 4 . SEM of the mycelium growing edge in the fish epidermis (asterisk). Scale bar $=100 \mu \mathrm{m}$. Fig. 5 . In the periphery of the fungal lesion hyphae with attached cells are frequently found. These cells have irregular shapes, with cytoplasmic 


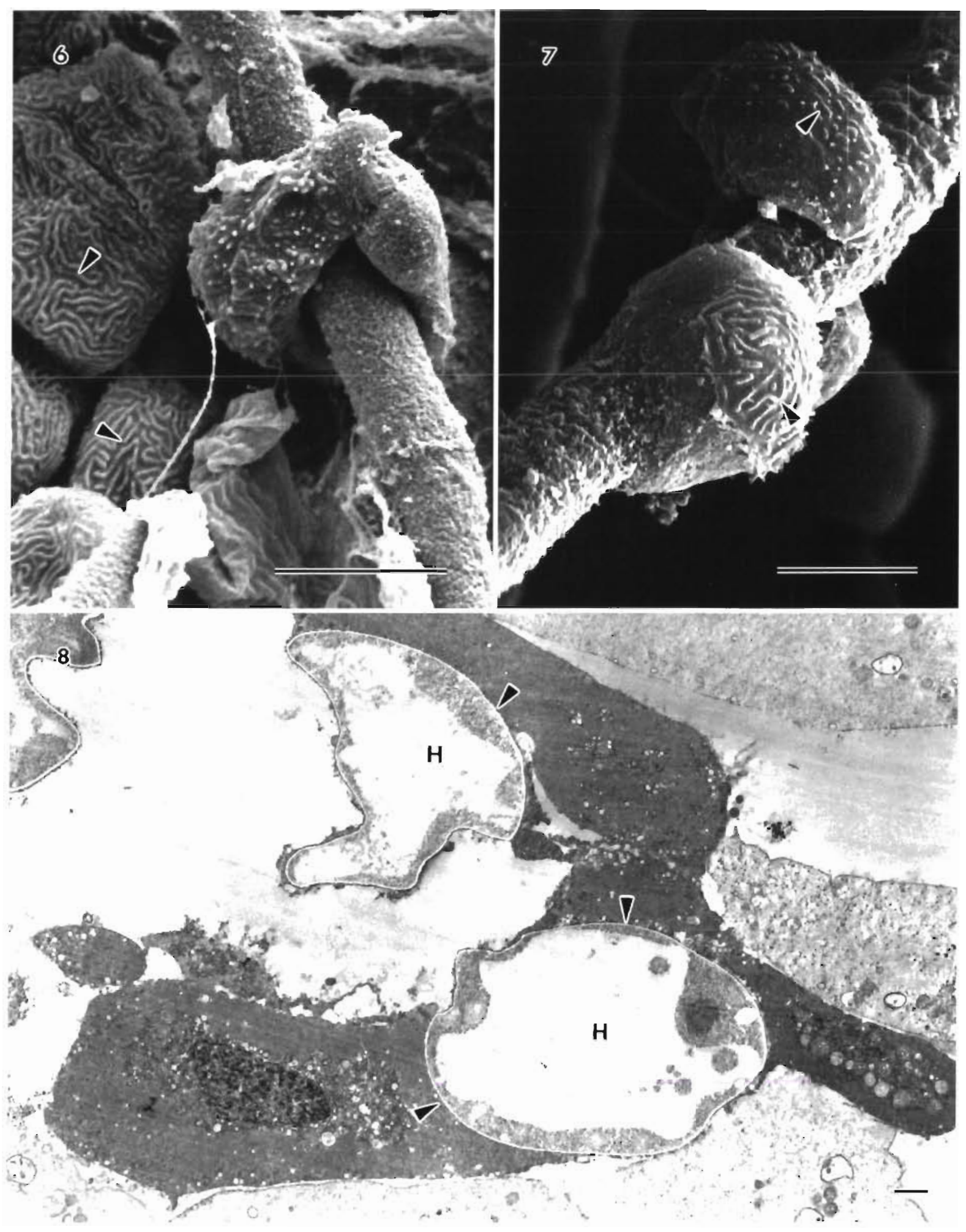

Figs. 6 to 8. Saprolegnia parasitica in Salmo trutta. Fig. 6. Hypha with attached cells. Note the microridges on the surface of the underlying epithelial fish cells (arrowheads). Scale bar $=10 \mu \mathrm{m}$. Fig. 7. Hypha with attached cells. These cells show remains of superficial microridges (arrowheads). Scale bar $=10 \mu \mathrm{m}$. Fig. 8. TEM of hyphae with attached cells. Generally, there is no intercellular space (arrowheads) between cell and hypha $(\mathrm{H})$. Note the electron density of the attached cell. Scale bar $=1 \mu \mathrm{m}$ 
mitochondria, endoplasmic reticulum and various vesicles in the cytoplasm. However, the most notable feature of these cells was the presence of a dense mass of filaments scattered in the cytoplasm (Fig 10) which in most cases masked the cytoplasmic organelles.

The contact between the hyphal and cellular surfaces was always very close, generally without an intercellular space between them (Fig. 9). When 2 or more cells surrounded a single hypha, the cell surfaces were in intimate contact forming a cover around the hypha. However, we have never observed desmosomes between such adjacent cells. Many of the attached cells showed degenerative signs, such as vacuolated cytoplasm, disorganised organelles, and lack. of continuity of the cellular membrane (Fig. 11).

\section{DISCUSSION}

Because of the arrangement of the cells, which were adhered to the hyphae surface and could surround them almost completely, they were called 'Capsule Cells' (CpCs) (López-Dóriga 1995). We emphasize that CpCs were not found in all the skin samples that we observed, but only in those which showed an advanced degree of infection. The development of epidermal lesions caused by Saprolegnia in brown trout has been categorised into 4 grades of increasing severity (López-Dóriga 1995). According to this classification, CpCs were evident in the severest infections (Grade 4), which are characterised by the presence of numerous hyphae, a residual epidermis, and lack of continuity of the basement membrane.

At ultrastructural level, the $\mathrm{CpCs}$ had similarities with filament-containing cells (FCCs) which are the main structural element of fish epidermis. FCCs have a central nucleus and a cytoplasm, in which 2 zones can be distinguished: the perinuclear zone, where the organelles are situated, and the peripheral zone, occupied by filaments. Although in CpCs the 2 cytoplasmic areas were not as well defined as in FCCs, the CpCs organelles were also perinuclear and the filaments extended throughout a large part of the cytoplasm. In the epidermis of channel catfish infected by Saprolegnia spp., Xu \& Rogers (1991) noted the presence of some epithelial cells denser than normal cells in which it was difficult to identify the organelles.

Cells attached to Saprolegnia hyphae have been seen by light microscopy in different species of salmonid, both in naturally (Willoughby 1972, 1989) and experimentally (Sohnle \& Chusid 1983) infected fish. From these studies, it was suggested that the attached cells were inflammatory cells, mainly lymphocytes and neutrophils, based on their positive reaction to peroxidase staining (Sohnle \& Chusid 1983) or the presence of pseudopodia (Wood et al. 1986). Our attempts to detect peroxidase in the CpCs were unsuccessful, probably because of the high degree of alteration of the integument, since in all cases the epidermis was lost during the staining process. However, the cells we observed did not have the characteristic features of the inflammatory cells described in the epidermis of brown trout. On the one hand, CpC nuclei were never multilobed and their cytoplasm did not possess the cytoplasmic granules characteristic of the epidermal neutrophils (Martinez \& López-Dóriga 1995). On the other hand, the CpC nuclei were surrounded by abundant cytoplasm, unlike lymphocytes described in the same species (Peleteiro \& Richards 1985, 1990). Finally, the CpCs cytoplasm did not show phagocytic vacuoles and other cellular features which are characteristic of epidermal macrophages (Martínez et al. 1994). Therefore, we conclude that the $\mathrm{CpCs}$ have no leucocytic features. Instead, they have cytoplasmic filaments, which are regarded as proof that a cell is of epithelial nature. In addition, the absence of inflammatory responses around invading Saprolegnia hyphae was noted not only in salmonid fish (Pickering \& Richards 1980 , Pickering \& Willoughby 1982, Bruno \& Stamps 1987 , Álvarez et al. 1988, 1995, López-Dóriga 1995), but also in channel catfish (Xu \& Rogers 1991, Bly et al. 1992). From our results, we suggest that the $\mathrm{CpCs}$ could be modified FCCs. The nature of the changes which lead to the transformation of FCC to CpC is not yet known.

The function of these attached cells is not clear. Sohnle \& Chusid (1983) suggested that they could work as protective agents against the fungi, on the basis of the results of Diamond et al. (1978) in humans. The latter observed that blood neutrophils were unable to phagocyte the long Candida albicans hyphae, but they attached to them and there was release of enzymes and lysozyme by degranulation, so that the fungus was damaged. This mechanism has been observed in other mammals infected by different fungi (Murphy 1991), Sohnle \& Chusid (1983) and Bly et al. (1992) suggested that a similar mechanism could occur in fish infected by fungi. Although we did not observed any signs of alteration in the hyphae resulting from their association with CpCs, the attached fish cells could be exerting a lytic effect on the Saprolegnia hyphae, both internal (Wood et al. 1986) and external (Willoughby 1989). However, all these ideas were based on the hypothesis that these adhered cells were leucocytic cells. Non-leucocytic cells interacting with fungi have been reported in mammals. Histoplasma capsulatum yeast cells can be phagocyted by human endothelial cells as well as by hamster tracheal epithelial cells (see Murphy 1991). Exactly how the interaction non-leucocytic cells/fungus relates to the fungal disease and the host defences is not understood. 


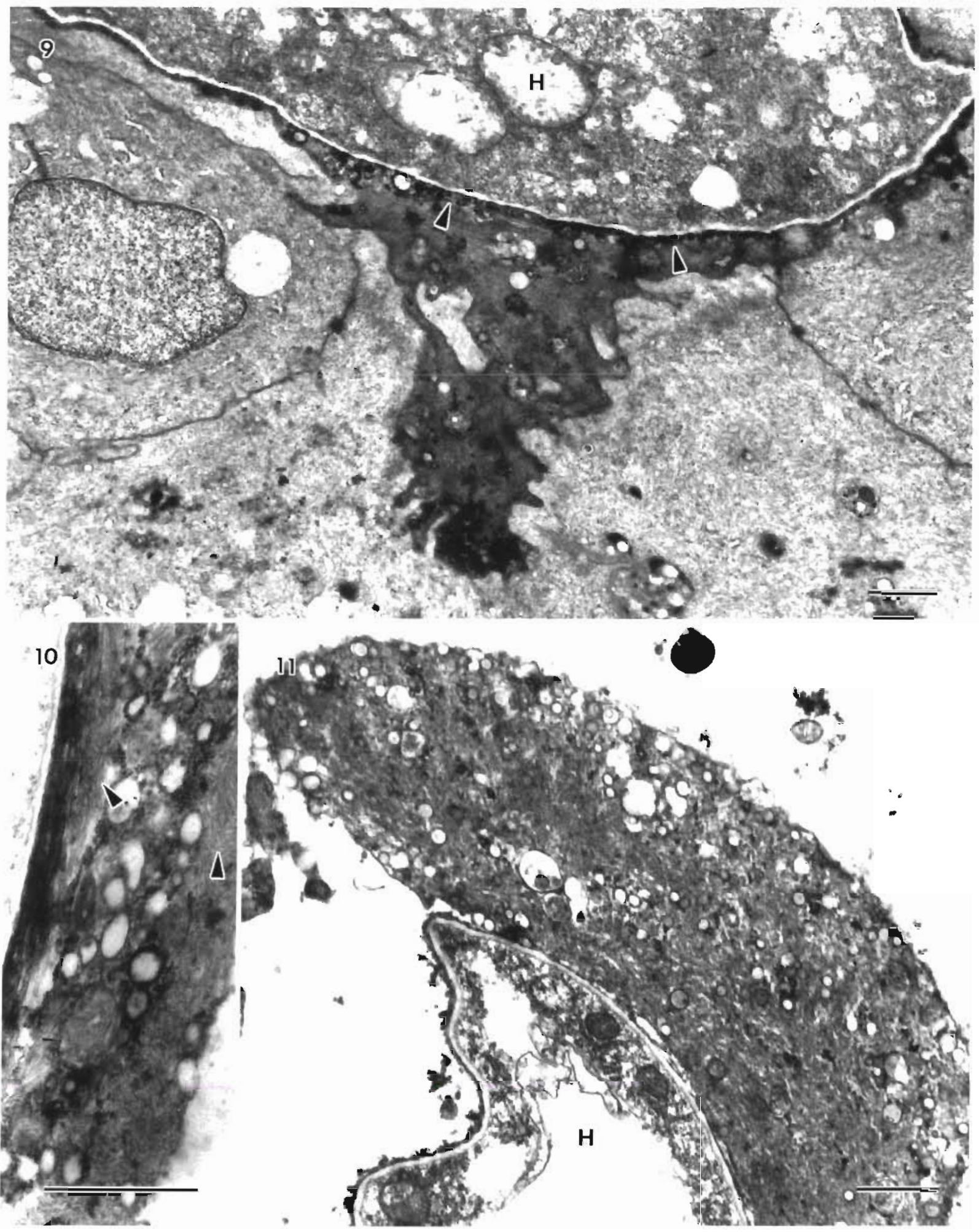

Figs 9 to 11 Salmo trutta infected with Saprolegnia parasıtica Fig. 9. Detall of the close contact (arrowheads) between attached cell and hypha $(\mathrm{H})$ Scale bar $=1 \mu \mathrm{m}$ Fig. 10. The cytoplasm of attached cells is mainly occupied by a dense mass of filaments (arrowheads) masking the organelles Scale bar $=1 \mu \mathrm{m}$ Fig. 11. Most of the attached cells show degenerative signs such as vesiculated cytoplasm and non-contınuous cellular membrane Scale bar $=1 \mu \mathrm{m}$ 
In fish, Noga et al. (1989) reported the presence of inflammatory cells with epithelial features (desmosomes, tonofilaments, and cytokeratine) in granulomes from different diseases. These authors suggested that the phagocytes could not be involved in the inflammatory process and that some agents could lead to a different cellular reaction. The presence of Saprolegnia hyphae in the epidermis of brown trout, and the lack of an inflammatory response with neutrophils and macrophages in naturally infected fish, could lead to a different cellular reaction in which the CpCs would be involved. In fact, the epithelial cells and other types of cells of the thymus (Álvarez et al. 1995), spleen and kidney (Álvarez et al. 1988) showed an increased phagocytic activity in Saprolegnia-infected brown trout.

Although the ultrastructural observations seem to show clearly the CpCs are not leucocytic cells, more studies are necessary in order to determine the nature of the CpCs and their possible role in Saprolegnia infections.

Acknowledgements. We are indebted to Dr G. G. Baschwitz for preparing the SEM samples. We thank Oliva Buelga and José Molina for technical assistance. Durnng this study, M.V.L.-D. was recipient of an FYCIT research grant from the Gobierno del Principado de Asturias (Spain).

\section{LITERATURE CITED}

Alderman DJ (1982) Fungal diseases of aquatic animals. In: Roberts RJ (ed) Microbial diseases of fish. Academic Press, New York, p 189-242

Alexander JB (1985) Non-immunoglobulin humoral defenses in fish. In: Manning MJ, Tatner M (eds) Fish immunology. Academic Press, New York, p 133-140

Álvarez F, Rázquin B, López-Fierro P, Castillo A, Zapata A, Villena A (1987) Histopatología del timo de la trucha común Salmo trutta fario infectada por Saprolegnia sp. Cuad Marisq Public Téc 12:609-614

Álvarez F, Rázquin B, Villena A, López-Fierro P, Castillo A, Zapata A (1988) Alterations in the peripheral lymphoid organs and differential leucocyte counts in Saprolegniainfected brown trout, Salmo trutta fario. Vet Immunol Immunopathol 18:181-193

Álvarez F, Villena A, Zapata A, Rázquin B (1995) Histopathology of the thymus in Saprolegnia-infected wild brown trout, Salmo trutta L. Vet Immunol Immunopathol 47:163-172

Beakes GW, Wood SE, Burr AW (1994) Features which characterize Saprolegnia isolates from salmonid fish lesions. A review. In: Mueller GJ (ed) Salmon saprolegniases. Boneville Power Administration, Portland, p 33-66

Bly JE, Lawson LA, Abdel-Aziz ES, Clem LW (1993) Channel catfish, Ictalurus punctatus, immunity to Saprolegnia sp. J Appl Aquacult 3:35-50

Bly JE, Lawson LA, Dale DJ, Szalai AJ, Durborow RM, Clem LW (1992) Winter saprolegniosis in channel catfish. Dis Aquat Org 13:155-164

Bruno DW, Stamps DJ (1987) Saprolegniasis of Atlantic salmon, Salmo salar L., fry. J Fish Dis 10:513-517

Diamond RD, Krzesicki R, Wellington J (1978) Damage to pseudohyphal forms of Candida albicans by neutrophils in the absence of serum in vitro. J Clin Invest 61:349-359

Hayat MA (1981) Fixation for electron microscopy. Academic Press, New York

Lewis PR, Knight DP (1977) Staining methods for sectioned material. In: Glauert AM (ed) Practical methods in electron microscopy. Elsevier North-Holland, Amsterdam, p 1-311

López-Dóriga MV (1995) Patología ultraestructural del tegumento de truchas (Salmo trutta L.) infectadas por Saprolegnia. PhD thesis, Universidad de Oviedo

Martínez JL, López-Dóriga MV (1995) Neutrophil granulocytes in the epidermis of the brown trout, Salmo trutta L.: ultrastructural characterization. J Submicrosc Cytol Pathol $27: 459-465$

Martínez JL, López-Dóriga MV, Baschwitz GG, Fernández-B de Quirós C (1994) Ultrastructural observations on pigmented macrophages in the epidermis of the brown trout (Salmo trutta L.). J Submicrosc Cytol Pathol 26:481-487

Murphy JW (1991) Mechanisms of natural resistance to human pathogenic fungi. Annu Rev Microbiol 45:509-538

Noga EJ (1993) Water mold infections of freshwater fish: recent advances. Annu Rev Fish Dis 3:291-304

Noga EJ, Dykstra MJ, Wright JF (1989) Chronic inflammatory cells with epithelial cell characteristics in teleost fishes. Vet Pathol 26:429-437

Peleteiro MC, Richards RH (1985) Identification of lymphocytes in the epidermis of the rainbow trout, Salmo gairdneri Richardson. J Fish Dis 8:161-172

Peletciro MC, Richards RH (1990) Phagocytic cells in the epidermis of rainbow trout, Salmo gairdneri Richardson. J Fish Dis 13:225-232

Pickering AD, Richards RH (1980) Factors influencing the structure, function and biota of the salmonid epidermis. Proc R Soc Edinb 79B:93-104

Pickering AD, Willoughby LG (1982) Saprolegnia infections of salmonid fish. In: Roberts RJ (ed) Microbial diseases of fish. Academic Press, London, p 271-297

Sohnle PG, Chusid MJ (1983) Defense against infection with filamentous fungi in rainbow trout. Comp Biochem Physiol 74 A:71-76

Spurlock BO, Skinner M, Kattine A (1966) A simple rapid method for staining epoxy embedded specimens for light microscopy with the polychromatic stain paragon-1301. Am J Clin Pathol 46:252-258

Willoughby LG (1972) U.D.N. of Lake District trout and char outward signs of infection and defence barriers examined further. Salmon Trout Mag 195:149-158

Willoughby LG (1978) Saprolegniasis of salmonid fish in Windermere: a critical analysis. J Fish Dis 1:51-67

Willoughby LG (1989) Continued defence of salmonid fish against Saprolegnia fungus, after its establishment. J Fish Dis 12:63-67

Willoughby LG (1994) Fungi and fish diseases. Pisces Press, Stirling

Willoughby LG, Pickering AD (1977) Viable Saprolegniaceae spores on the epidermis of the salmonid fish Salmo trutta and Salvelinus alpinus. Trans Br Mycol Soc 68:91-95

Wood SE, Willoughby LG, Beakes GW (1986) Preliminary evidence for inhibition of Saprolegnia fungus in the mucus of brown trout, Salmo trutta L., following experimental challenge. J Fish Dis 9:557-560

Wood SE, Willoughby LG, Beakes GW (1988) Experimental studies on uptake an interaction of spores of the Saprolegnia diclina-parasitica complex with external mucus of brown trout (Salmo trutta). Trans Br Mycol Soc 90:63-73

Xu D, Rogers WA (1991) Electron microscopy of infection by Saprolegnia spp. in channel catfish. J Aquat Anim Health $3: 63-96$ 